\title{
Solutions for subsidence in the California Delta, USA, an extreme example of organic-soil drainage gone awry
}

\author{
Steven J. Deverel ${ }^{1}$, Sabina Dore ${ }^{1}$, and Curtis Schmutte ${ }^{2}$ \\ ${ }^{1}$ HydroFocus, Inc., Davis, CA 95618, USA \\ ${ }^{2}$ Curtis Schmutte Consulting, Davis, CA 95618, USA \\ Correspondence: Steven J. Deverel (sdeverel@hydroFocus.com)
}

Published: 23 April 2020

\begin{abstract}
The Sacramento-San Joaquin Delta is at the heart of California's water supply system that provides water for irrigation and human consumption. It is also home to subsiding organic soils, decreasing native aquatic species populations, water quality degradation, vulnerable levees (levees are equivalent to dikes) and decreasing agricultural viability. There has been substantial progress in the interdisciplinary understanding and quantification of the nature and effects of subsidence and its mitigation. Because of the need for a drained rootzone, farming of crops such as vegetables, trees, vines, corn and alfalfa, results in an ongoing unsustainable cycle of continuing peat oxidation and deepening of drainage ditches to compensate for elevation loss. Despite substantial evidence for the increasing risks to the State's economy and water supply, the unsustainability of the status quo, and evidence for the benefits of alternatives, there has been limited progress in converting to land uses that can reduce, stop and reverse subsidence. Our overall approach has been to measure land-surface elevation changes; understand, quantify and model subsidence and greenhouse gas emissions from drained organic soil, and evaluate alternate land uses. Subsidence rates vary from less than 0.5 to over $2 \mathrm{~cm} \mathrm{yr}^{-1}$, depending primarily on depth to groundwater and soil organic matter content. The primary cause of subsidence is the oxidation of organic matter, which has resulted in elevations of -3 to $-9 \mathrm{~m}$ on about $100000 \mathrm{ha}$. Using the results from micrometeorological measurements and modelling, we estimate that organic-matter oxidation causes an annual emission of over $2 \times 10^{6} \mathrm{t}$ of $\mathrm{CO}_{2}$-equivalent which represents about $21 \%$ of the State's plant-based agricultural emissions.

Rewetting of the peat soils is emerging as a viable solution. Rice and wetlands stop and (in the case of wetlands) reverse the effects of subsidence and result in a net greenhouse-gas emission reduction benefit. Wetlands accrete about $3 \mathrm{~cm}$ of soil per year, can break the unsustainable subsidence/drainage cycle, reverse the trajectory of increasing hydraulic pressures on levees, reduce the probability of levee failure and seepage onto islands (islands are equivalent to polders), and may provide material for biofuels and animal feed. The recent implementation of a methodology for quantification of the GHG benefit is facilitating land use conversion and participation in the carbon market.
\end{abstract}

\section{Background}

Peatlands worldwide occupy about $3 \%$ of the land surface but contain almost $20 \%$ of all organic carbon stored in terrestrial systems. Carbon sequestration results from biomass production under saturated anaerobic conditions. Drainage of peatlands alters the carbon dynamics of peat soils; aerobic conditions accelerate decomposition of the carbon stocks accumulated over centuries under flooding.

\section{Sacramento-San Joaquin Delta, USA}

The Sacramento-San Joaquin Delta peatlands (Fig. 1) represent an important extreme example of soil oxidation subsidence and collateral detrimental effects. About $5 \times 10^{9} \mathrm{~m}^{3}$ of peat accumulated during the last 7000 years of wetland development (Deverel and Leighton, 2010). Drainage of the peatlands, which began in the mid-19th century, resulted in the loss of about one-half of this volume. This degradative 


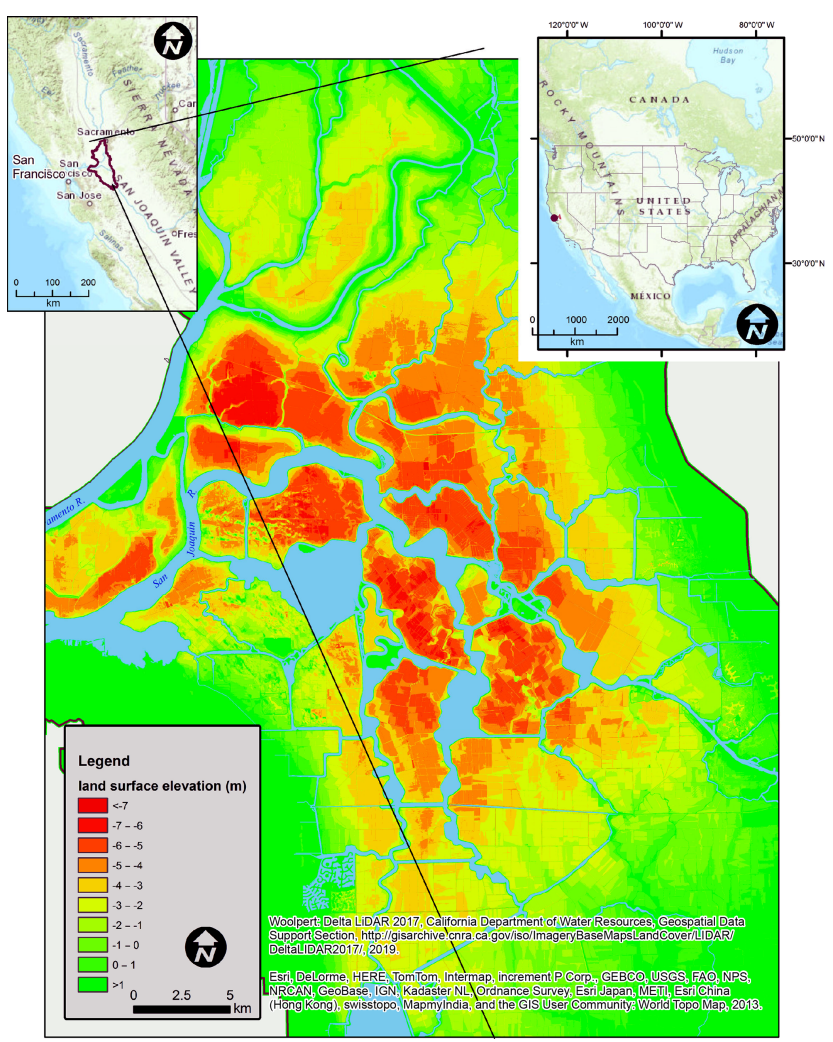

Figure 1. Location of the Sacramento-San Joaquin Delta and 2017 elevations.

process is on-going (Deverel et al., 2016a) and has resulted in elevations of Delta islands as low as $9 \mathrm{~m}$ below sea level (Fig. 1).

The current trajectory of Delta land- and watermanagement is unsustainable. Key indicators include native species decline (e.g. Moyle et al., 2016), decreased arability (Deverel et al., 2015), increased pressure on levees and water supply vulnerability (Deverel et al., 2016b), and large greenhouse gas emissions (Hemes et al., 2019). The State of California has established ambitious co-equal goals for the Delta: to provide a more reliable water supply and to protect, restore and enhance the Delta ecosystem (Delta Stewardship Council, 2018).

Alternate land uses such as permanently flooded, managed wetlands provide a substantial net GHG emissions reduction benefit relative to the status quo and mitigate and reverse subsidence, thereby reducing levee vulnerability over time and contributing to increased water supply reliability and resiliency (Deverel et al., 2014; Miller et al., 2008; Hemes et al., 2019). In this paper, we explore possible solutions to the Delta subsidence problem through the adaptation of alternate land uses.

\section{Approach and methods}

We investigated the practical aspects and potential regional and state-wide benefits of conversion of peat soils in the Delta to alternative land uses as a solution to the subsidence and sustainability problems. Our approach is holistic in that we explored and analysed the available data for greenhouse-gas (GHG) emissions reductions and associated financial benefits for landowners. First, we used the SUBCALC model (Deverel et al., 2016a) to estimate Delta-wide GHG emissions in relation to California's overall agricultural emissions. Next, we explored the use of wetlands for reversing the effects of subsidence through accretion measurements using sedimentation erosion tables (Boumans and Day, 1993). We assessed the use of the protocol for the Deltaic Wetlands Restoration (Deverel et al., 2017a). Lastly, we assessed the benefit to increasing levee stability, water-supply reliability and ecosystem benefits.

\section{Results and discussion}

\subsection{Delta and California GHG emissions}

Using the SUBCALC model described in Deverel et al. (2016a), and nitrous oxide data described in Deverel et al. (2017b) we estimated that the total annual GHG emission in the Delta at about $2 \times 10^{6}$ metric tons of $\mathrm{CO}_{2}$ equivalents ( $\mathrm{MTCO}_{2}$ eq.) (Fig. 2). Estimated average per hectare annual $\mathrm{MTCO}_{2}$ eq. varied primarily due to spatially variable soil organic matter content and depth to groundwater. The largest GHG emissions originate from the central Delta islands where the highest organic matter content soils are located. Deverel and Leighton (2010) discussed the factors affecting the distribution of soil organic matter content: reclamation date, geomorphology, etc.

California is home to about 17 million agricultural hectares. The total estimated GHG emissions from Californian agricultural land, $8 \%$ of California's total GHG emissions, was calculated as $33.8 \times 10^{6} \mathrm{MT} \mathrm{CO}_{2}$ eq. in 2016 (California Air Resources Board, 2019). Annual agricultural animal emissions were estimated at $24.3 \times 10^{6} \mathrm{MTCO}_{2}$ eq. Therefore, about 100000 ha of Delta organic soils, $0.5 \%$ of California's agricultural land, account for about $6 \%$ of total California agricultural emissions, and $21 \%$ of non-animal agricultural GHG emissions. Stopping Delta GHG emissions will help California reach its goals to reduce State-wide GHG emissions by $80 \%$ below 1990 levels by 2050 (California Air Resources Board, 2018).

\subsection{Changing the trajectory, rewetting of peat soils}

Multiple publications have demonstrated the GHG and subsidence-reversal benefits of rewetting Delta peat soils. Most recently, Hemes et al. (2019) summarized the GHG benefit of conversion to wetlands for 36 site-years of Delta 


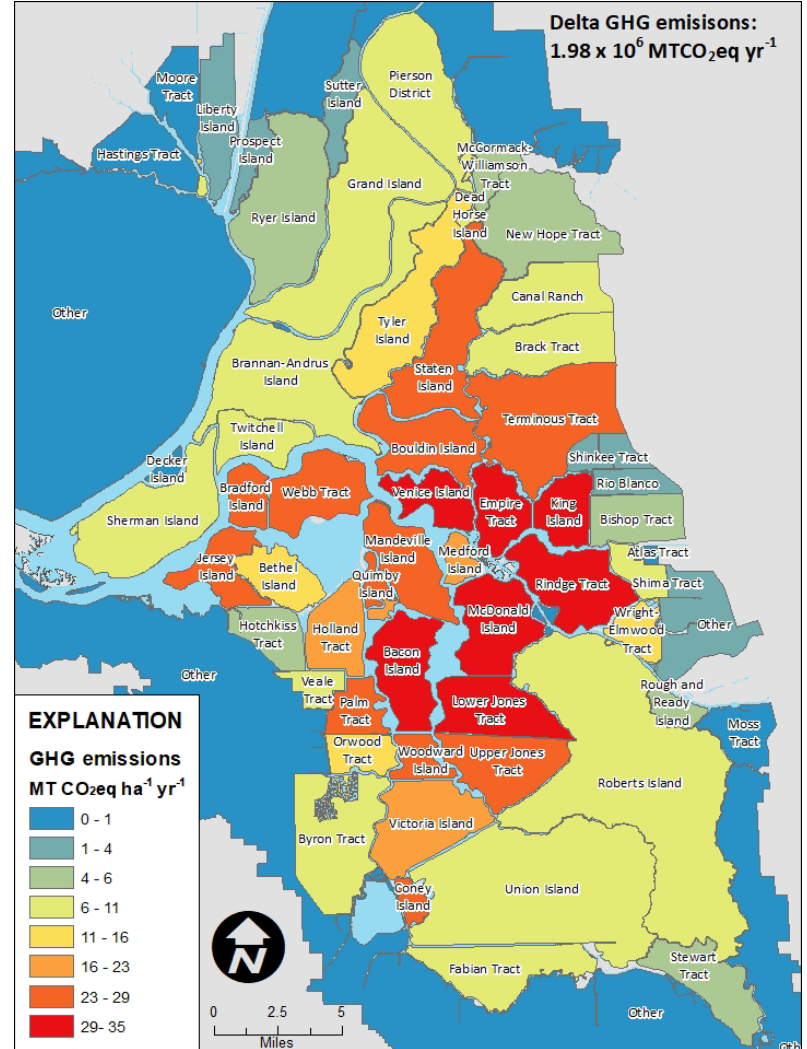

Figure 2. Present-day estimated annual GHG emissions in $\mathrm{MTCO}_{2}$ eq. ha ${ }^{-1} \mathrm{yr}^{-1}$.

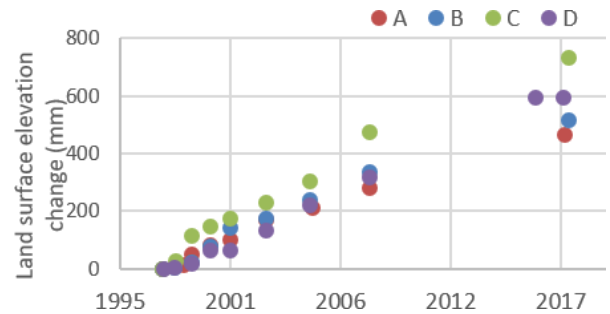

Figure 3. Land-surface elevation change in the Twitchell Island managed wetland. A, B, C and D are sites for sedimentation erosion measurements.

eddy covariance $\mathrm{CO}_{2}$ and $\mathrm{CH}_{4}$ ecosystem flux data. Miller et al. (2008) and Deverel et al. (2014) presented accretion data and associated subsidence mitigation benefits.

We herein present accretion data collected on the Twitchell Island 2 ha West Pond Wetland described in Miller et al. (2008) and Deverel et al. (2014). This wetland created in 1997 sustained long-term average accretion rates ranging from 2.35 to $3.6 \mathrm{~cm} \mathrm{yr}^{-1}$ for 20 years (Fig. 3).

Figure 4 illustrates trajectory reversal due to wetlands creation on peat soils. During 4.5 years prior to wetland construction, inelastic subsidence measured at an extensometer was about $1 \mathrm{~cm} \mathrm{yr}^{-1}$ in a corn field on Twitchell Island (Deverel et al., 2016a). A 322 ha subsidence-mitigation wetland

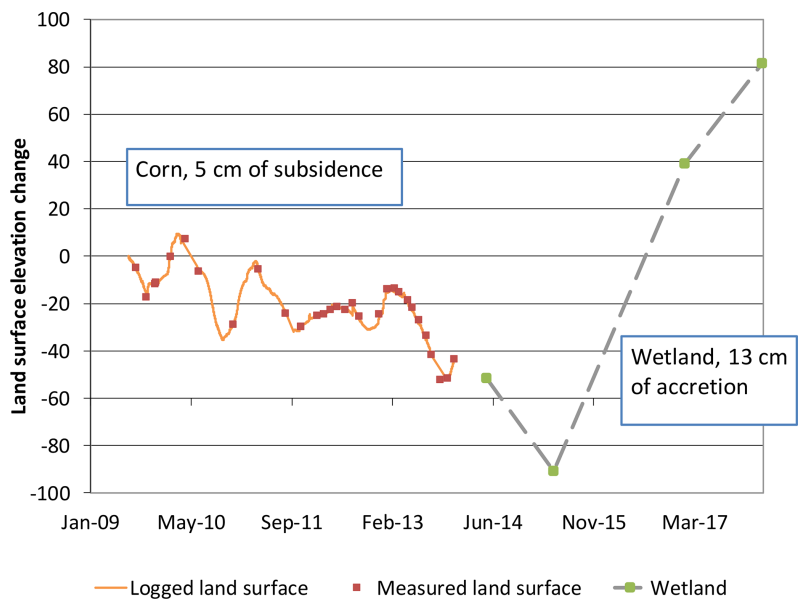

Figure 4. Subsidence and the wetland trajectory reversal in land accretion.

was created in 2014 included the location of an extensometer. Subsequent accretion measurements using the sedimentation erosion table at the extensometer location indicated accretion of $13 \mathrm{~cm}$ from May 2014 to February 2018 averaging about $3 \mathrm{~cm} \mathrm{yr}^{-1}$.

\subsection{Present-day consequences and risks, and benefits of changing the current trajectory}

\subsubsection{Levees and California's water supply}

Under business as-usual practices, the Delta region is unsustainable because of threats to levee integrity (URS Corporation and Jack R. Benjamin \& Associates, Inc., 2009). Levees can be reinforced and augmented to reduce risk, but all risk cannot be eliminated (Arcadis, 2016). Levees fail in multiple ways from external and internal processes; destabilizing inertial loading, sliding along a preferred failure plane, slumping or spreading, seepage, erosion, and overtopping during extreme high-water events (Moss and Eller, 2007).

Delta stressing events include floods, earthquakes, animal burrowing, and wind waves, which correspond to failure modes of under- and through seepage, overtopping, seismic deformation, liquefaction and erosion. The consequences of levee failure include loss of agricultural production, water supply disruption, habitat loss and species alteration, water quality degradation, infrastructural destruction and disruption, and loss of life. A primary concern is the failure of levees surrounding large deeply subsided islands in the southern and western Delta which can result in salinity intrusion. Mitigating subsidence is essential for limiting salinity intrusion since its magnitude is directly related to the depth of subsidence. Therefore, subsidence mitigation and stability of these levees are key elements in ensuring the stability of California's water supply for a large portion of 27 million people and millions of ha of irrigated agriculture. Since 1950, there have been 87 Delta levee failures and island floods. 
Subsidence contributed to levee failures by lowering island surfaces and thus creating increased height differences between island surfaces and adjacent surface-water levels, and augmented hydraulic forces against levees which contributed to levee internal failures. Seepage under levees which is exacerbated by subsidence can erode levee foundation materials and slowly degrade levee stability over time. The underseepage susceptibility adjacent to Delta project levees is high to very high (URS Corporation and Lettis Fugro-William \& Associates, 2011; Kleinfelder and Tetratech, 2011; URS Corporation and Jack R. Benjamin \& Associates, Inc., 2008a). As the overlying peat soil disappears, upward hydraulic gradients increase and exit gradients in drainage ditches reach critical values which can lead to levee foundation erosion.

Deverel et al. (2014) described trajectory reversing potential of wetlands; exit gradients increasing towards critical values were projected to reverse with the implementation of wetlands. Groundwater flow modelling presented in Deverel et al. (2017c) demonstrated substantial reduction in seepage onto islands with widespread conversion to wetlands and rice. Moreover, levee static stability analysis presented in Deverel et al. (2016b) demonstrated the potential reduction in levee failure rates with wetlands and rice cultivation.

\subsubsection{Effects on water quality, arability and economy}

Ongoing subsidence contributes detrimentally to water quality in Delta channel waters. Ongoing system operation results in relatively high costs for municipal water treatment because of the presence of dissolved organic carbon (DOC) (Chen et al., 2010), contributed partially by the oxidation of the peat soils. Dissolved organic carbon concentrations in Delta export waters consistently exceed the State's water-quality objective. Formation of disinfection by-products resultant from high DOC concentrations has required utilities to increase treatment costs. As subsidence ensues, island drainage export loads of dissolved organic carbon and methyl mercury to Delta channels also increase (Deverel et al., 2007; Heim et al., 2009). Drainage costs will increase because of larger pumping lifts. Volumes below sea level on Delta islands will continue to increase with decreasing land-surface elevations and sea level rise.

When levees fail and islands flood, saline water can be drawn into the Delta, jeopardizing water supply and water quality for agriculture. State-wide costs as a result of levee failure include agricultural losses, urban and agricultural water user losses from water supply disruption, and the lost use of major infrastructure. Multiple publications describe consequences of Delta levee failure. URS Corporation and Jack R. Benjamin \& Associates, Inc. (2008b) estimated the state-wide costs for water supply reduction and infrastructural damage to range from tens of millions of dollars to multiple billions of dollars, for one to multiple flooded islands due to extreme hydrologic events.
The Delta Risk Management Strategy project estimated that a water supply disruption of approximately 3 to 4 months, such as could be required to repair a large levee breach in the summer months, could cost approximately USD 225 million (in 2018 USD) (URS Corporation and Jack R. Benjamin \& Associates, Inc., 2008b). The cost of a two to three-year supply interruption resultant from multiple levee breaches may cost USD 48 billion or more (in 2018 USD) (Howitt, 2007).

The Delta Risk Management Strategy Project considered potential impacts to California's economy from various levee failure scenarios with estimates up to and exceeding USD 100 billion with multiple and simultaneous levee failures. The Department of Water Resources spent almost USD 1 billion since the mide-1970s on levee maintenance and improvement.

Documented increased wet and non-farmable and marginally farmable land resulting from subsidence and consequent seepage from the 1980s to 2012 (Deverel et al., 2015) brings into question long-term sustainability of the status quo. Seepage rates onto islands have increased and are predicted to increase in the future (Deverel et al., 2015, 2017c). Wet, nonfarmable, and marginally farmable areas affects the future of farming and property values.

\subsection{Moving towards a more sustainable future}

Despite substantial evidence for the increasing risks to the State's economy and water supply, the unsustainability of the status quo, and evidence for the benefits of alternative land uses, there has been limited progress in converting to land uses that can reduce, stop, and reverse subsidence. Economic incentives are needed for agricultural producers to convert to more sustainable land uses. Potential mechanisms include income from rice cultivation, economic use of wetlands, the California low carbon fuel standard, and the carbon offset market.

\subsubsection{Rice cultivation}

Deverel et al. (2016b) provided evidence for the subsidencestopping benefit of rice cultivation on Delta peat soils. Deverel et al. (2017b) presented a vision of a mosaic of subsidence-mitigating land uses that includes rice and wetlands which can provide reasonable agricultural income and a substantial GHG-reduction benefit. Wetlands also can provide a water quality benefit by serving as a filtration system for agricultural drainage waters. The primary impediment to large-scale rice cultivation and wetlands is the investment in infrastructure and machinery.

\subsubsection{Carbon offsets}

The protocol for restoration of California Deltaic wetlands (Deverel et al., 2017a) has facilitated the verification and 
may lead to trading of carbon-offset credits for restored wetlands on State-owned Delta islands. Approximately 690 ha of wetlands have been registered and in 2018 yielded a verified GHG emissions reduction of about $18127 \mathrm{MT} \mathrm{CO}_{2}$ eq. $\mathrm{yr}^{-1}$ which can yield income generally commensurate with current agricultural lease values on State-owned islands. However, greater income is required to convince private landowners to enrol in the carbon market. The required 40 -year commitment can also be an impediment. Transition from the voluntary to the California carbon offset compliance market is expected to result in higher prices per $\mathrm{MTCO}_{2}$ eq. (approximately USD 15) and prices are projected to rise to over USD 30 per $\mathrm{MTCO}_{2}$ eq. within 10 years which will likely increase land-owner participation.

\subsubsection{Experimenting with paludiculture}

Research in the Delta region thus far has focused on the increased use of managed, permanently flooded wetlands and rice production. The next steps in this process will be the experimental use of perennial wetland species for commercial biomass production (paludiculture). These efforts will draw on expertise and experience locally and elsewhere to initiate a Delta pilot project. California's low carbon fuel standard may provide greater incentives for landowners than the landbased carbon-offset market.

\subsubsection{Levee benefits of alternate land uses}

Carbon-sequestration wetlands can potentially reduce the future levee maintenance and failure costs. Specifically, recent analyses demonstrated that annual levee seepage and slope stability failure risks will increase $17 \%$ in 50 years with no change to Delta land uses. Using geotechnical analysis, it was determined that wetlands could reduce the risks of levee failure by $50 \%$ by 2070 .

\subsection{Summary and conclusions}

We herein provided evidence for the unsustainability of the status quo in the Sacramento-San Joaquin Delta, and the difficulties in finding solutions. Almost USD 1 billion have been spent on levee maintenance and improvements since the mid1970s and it is projected that up to USD 4 billion will be required for future Delta levee improvements to meet local requirements. Substantial additional funding will be required to compensate for climate changes and these improvements will not directly address the under seepage problem. Subsidence has been the primary motivating force leading to the need for levee improvements. Continued subsidence perpetrates a cycle of deepening of drainage ditches which exposes additional organic soil for oxidation, which in turn creates the need for deepening drainage ditches for maintenance of an aerated crop root zone. Rewetting of the peat soil breaks the subsidence-drainage ditch deepening cycle.
While progress has been made in the research and implementation of alternate rewetted landscapes, widespread adoption has heretofore not occurred. Wetlands accrete the land surface, reduce seepage onto islands, reduce probability of levee failure and can provide substantial GHG benefit. We envision an island mosaic of rice and wetlands (including paludiculture) that can, based on our research, lead to substantial reduction of subsidence and GHG emissions and maintain overall economic sustainability. The voluntary and California compliance carbon markets and harvesting of wetland biomass can likely provide income for incentivization of the creation of wetlands.

Data availability. Data is stored at figshare (https: //figshare.com/articles/Copy_of_Summary_Twitchell_Sherman_ graph_for_report_xlsx/12037740, Deverel, 2020).

Author contributions. SJD served as the primary writer and expert on subsidence. SD served as expert on greenhouse gas fluxes and carbon. CS served as expert on levees.

Competing interests. The authors declare that they have no conflict of interest.

Special issue statement. This article is part of the special issue "TISOLS: the Tenth International Symposium On Land Subsidence - living with subsidence". It is a result of the Tenth International Symposium on Land Subsidence, Delft, the Netherlands, 17-21 May 2021.

Acknowledgements. We gratefully acknowledge financial support for work described here from the Sacramento-San Joaquin Delta Conservancy, California Department of Water Resources, The Nature Conservancy and Metropolitan Water District of Southern California.

\section{References}

Arcadis: Risk analysis methodology: Delta levees investment strategy, available at: https: //cawaterlibrary.net/wp-content/uploads/2017/10/ DLIS-RISK-ANALYSIS-METHODOLOGY-JULY-2016-Final. pdf (last access: 2 April 2020), 2016.

Boumans, R. M. J. and Day, J. W.: High precision measurements of sediment elevation in shallow coastal areas using a sedimentation-erosion table, Estuaries, 16, 375-380, https://doi.org/10.2307/1352509, 1993.

California Air Resources Board: Assembly Bill 32 Scoping Plan, available at: https://ww3.arb.ca.gov/cc/scopingplan/scopingplan. htm (last access: 22 March 2020), 2018. 
California Air Resources Board: California Greenhouse Gas Emission Inventory - 2019 Edn., available at: https://www.arb.ca.gov/ cc/inventory/data/data.htm (last access: 22 March 2020), 2019.

Chen, W. H., Haunschild, K., Lund, J. R., and Fleenor, W. E.: Current and long-term effects of Delta Water Quality on drinking water treatment costs from disinfection byproduct formation, San Francisco Estuary Watershed Science, 8, 3, https://doi.org/10.15447/sfews.2010v8iss3art4, 2010.

Delta Stewardship Council: Delta Plan, available at: https:// deltacouncil.ca.gov/delta-plan/ (last access: 18 March 2020), 2018.

Deverel, S.: Summary_Twitchell Sherman graph for report.xlsx, available at: https://figshare.com/articles/Copy_of_Summary_ Twitchell_Sherman_graph_for_report_xlsx/12037740, last access: 27 March 2020.

Deverel, S. J. and Leighton, D. A.: Historic, Recent, and Future Subsidence, Sacramento-San Joaquin Delta, California, USA, San Francisco Estuary and Watershed Science, 8, 2, https://doi.org/10.15447/sfews.2010v8iss2art1, 2010.

Deverel, S. J., Leighton, D. A., and Finlay, M. R.: Processes Affecting Agricultural Drainwater Quality and Organic Carbon Loads in California's Sacramento-San Joaquin Delta, San Francisco Estuary Watershed Science, 5, 2, https://doi.org/10.15447/sfews.2007v5iss2art2, 2007.

Deverel, S. J., Ingrum, T., Lucero, C., and Drexler, J. Z.: Impounded Marshes on Subsided Islands: Simulated Vertical Accretion, Processes, and Effects, Sacramento-San Joaquin Delta, CA USA, San Francisco Estuary and Watershed Science, 12, 2, https://doi.org/10.15447/sfews.2014v12iss2art5, 2014.

Deverel, S. J., Lucero, C. E., and Bachand, S.: Evolution of Arability and Land Use, Sacramento-San Joaquin Delta, California, San Francisco Estuary and Watershed Science, 13, https://doi.org/10.15447/sfews.2015v13iss2art4, 2015.

Deverel, S. J., Ingrum, T., and Leighton, D. A.: Present-day Oxidative Subsidence of Organic Soils and Mitigation in the Sacramento-San Joaquin Delta, California, USA, Hydrogeol. J., 24, 569-586, https://doi.org/10.1007/s10040-016-13911, 2016a.

Deverel, S. J., Bachand, S., Brandenberg, S. J., Jones, C. E., Stewart, J. P., and Zimmaro, P.: Factors and Processes Affecting Delta Levee System Vulnerability, San Francisco Estuary and Watershed Science, 14, 4, https://doi.org/10.15447/sfews.2016v14iss4art3, 2016 b.

Deverel, S. J., Oikawa, P., Dore, S., Mack, S., and Silva, L.: The restoration of California deltaic and coastal wetlands, Version 1.1. November 2017, Methodology submitted to the American Carbon Registry, available at: http://americancarbonregistry. org/carbon-accounting/standards-methodologies/

restoration-of-california-deltaic-and-coastal-wetlands

(last access: 22 March 2020), 2017a.

Deverel, S., Jacobs, P., Lucero, C., Dore, S., and Kelsey, T.: Implications for Greenhouse Gas Emission Reductions and Economics of a Changing Agricultural Mosaic in the Sacramento-San Joaquin Delta, San Francisco Estuary and Watershed Science, 15, 3, https://doi.org/10.15447/sfews.2014v12iss2art5, $2017 \mathrm{~b}$.

Deverel, S. J., Leighton, D. A., Lucero, C., and Ingrum, T.: Simulation of Subsidence Mitigation Effects on Island Drain Flow, Seepage, and Organic Carbon Loads on Subsided Islands Sacramento-San Joaquin Delta,
San Francisco Estuary and Watershed Science, 15, 4, https://doi.org/10.15447/sfews.2017v15iss4art2, 2017c.

Heim, W. A., Deverel, S., Ingrum, T., Piekarski, W., and Stephenson, M.: Assessment of Methylmercury Contributions from Sacramento-San Joaquin Delta Farmed Islands, Final Report submitted to the California Valley Regional Water Quality Control Board, available at: http://www.swrcb.ca.gov/rwqcb5/ water_issues/tmdl/central_valley_projects/delta_hg/other_ technical_reports/Farmed-Island-Study_Aug2009.pdf (last access: 22 March 2020), 2009.

Hemes, K. S., Chamberlain, S. D., Eichelmann, E., Anthony, T., Valacha, A., Kasaka, K., Kuno, S., Daphne, V., Joe, S., Whendee, L., and Baldocch, D. D.: Assessing the Carbon and Climate Benefit of Restoring Degraded Agricultural Peat Soils to Managed Wetlands, Agr. Forest Meteorol., 268, 202-214, 2019.

Howitt, R.: Delta Dilemmas: Reconciling Water-Supply Reliability and Environmental Goals. Gianni Foundation of Agricultural Economics: Agricultural and Resource Economics Update, 10, 1-4, available at: http://s.giannini.ucop.edu/uploads/giannini_public/33/1d/ 331de356-88af-44c1-82ad-1a850e24f071/v10n4_1.pdf (last access: 22 March 2020), 2007.

Kleinfelder, P. W. A. and Tetratech: Final geomorphology technical memoranda and maps, South NULE Geomorphic Assessments, South Non-Urban Levee Evaluations Project Contract 4600008102, California Department of Water Resource, available at: http://www.dwr-lep.com (last access: 25 March 2020), 2011.

Miller, R. L., Fram, M. S., Wheeler, G., and Fujii, R.: Subsidence Reversal in a Re-established Wetland in the Sacramento-San Joaquin Delta, California, USA, San Francisco Estuary Watershed Science, 6, 3, https://doi.org/10.15447/sfews.2008v6iss3art1, 2008.

Moss, E. and Eller, M.: Estimating the Probability of Failure and Associated Risk of the California Bay Delta Levee System, in: Proceedings of Geo-Denver 2007, New Peaks in Geotechnics, 18-21 February 2007, Denver, CO, https://doi.org/10.1061/40914(233)21, 2007.

Moyle, P. B., Brown, L. R., Durand, J. R., and Hobbs, J. A.: Delta Smelt: Life History and Decline of a Once-Abundant Species in the San Francisco Estuary, San Francisco Estuary and Watershed Science, 14, 2, https://doi.org/10.15447/sfews.2016v14iss2art6, 2016.

URS Corporation and Jack R. Benjamin \& Associates, Inc.: Delta Risk Management Strategy phase 1 information. Topical area levee vulnerability, 2008a.

URS Corporation and Jack R. Benjamin \& Associates, Inc.: Delta Risk Management Strategy final phase 1 report. Risk Report: Section O, 2008b.

URS Corporation and Jack R. Benjamin \& Associates, Inc.: Delta Risk Management Strategy final phase 1 report. Risk report: section, prepared for the California Department of Water Resources, 2009.

URS Corporation and Lettis Fugro-William \& Associates: Final geomorphology technical memoranda and maps. North NULE Area Geomorphic Assessments NonUrban Levee Evaluations project contract 4600008101, available at: http://www.dwr-lep. com (last access: 25 March 2020), prepared for the California Department of Water Resources, 2011. 